\title{
Early Childhood Education in Nigeria: Issues and Problems
}

\author{
Tombowua Sooter \\ Department of Early Childhood Care and Education \\ College of Education, Katsina-Ala-Nigeria
}

\section{Doi:10.5901/jesr.2013.v3n5p173}

\begin{abstract}
The paper discusses the issues and problems of early childhood education in Nigeria. It establishes that the Federal Government of Nigeria in its National policy on Education has given official recognition to the development and provision of early childhood education in the country. This combined with a number of factors to give rise to an unprecedented expansion in the provision of child care and early childhood education institutions in the country. However, nearly all the early childhood education in the country is provided by private proprietors. It also identifies the inability of government among others to put to effect most of the measures it stated in the National Policy on Education aimed at ensuring that the policy objectives are achieved. It has also established that the provision of early childhood education will have positive influence on the educational development of children in later life.
\end{abstract}

Keywords: Education, Early Childhood, Issues, Problems

\section{Introduction}

Early years in life are the most important to the formation of intelligence, personality and social behaviour of a child. The year before a child reaches Kindergarten are among the most critical in his or her life to influence learning. That is why modern societies show serious concern for the education of their young ones by providing needed support to prepare them to succeed later in school (Ejieh, 2006). It is common practice in most societies to make provision for early childhood education programmes of various sorts for children below the official school-going age (usually 6years) mainly to prepare them for education in primary schools (Obidike, 2012). The Federal Government of Nigeria recognizes the importance of early childhood education in Nigeria and as a result it was given prominence in the National Policy of Education ( FRN, 2004) as one of the programmes in the Nigerian educational system.

Bagudo (2008), posited that reports across the globe revealed that an estimated figure of one hundred million children, struggle daily for survival in villages and cities, and are exposed to the risks of hunger, poverty, disease, illiteracy and abuses. In support of this view, Mahuta (2007) stresses that the need to address the problems and salvage these children and the next generation of children from these menace, has necessitated the programme of Early Childhood Care Development and Education (ECCDE).

Mahuta (2007) also stated that the aim of ECCDE is to foster the proper development of the children, identify and address their problems, harness their potentials, mould their character, enhance their learning, equip them for life, so that their actions are channeled towards positive personal, communal and global development in all ramifications of life. 


\section{A Brief History of Early Childhood Education in Nigeria}

In Nigeria, organized education of the child below primary school age did not receive official recognition until very recently, receive the attention it deserved. The concept of infant schools was introduced in Nigeria by the missionaries in the early $20^{\text {th }}$ century when such schools were set up in the Western and Eastern regions of Nigeria. Early Childhood education in the form of nursery school or pre-primary education as we know it today in Nigeria is largely a post-colonial development. The semblances of it during the colonial era were the Kindergarten and infant classes, which consisted of groups of children considered not yet ready for primary education. As groping for instruction in schools was not age-based during that period, some children aged six or even more, could be found in some of the infant classes (Tor-Anyiin, 2008). With the phasing out of infant classes, some parents began to feel the need for nursery schools.

During that period, (pre-independence) all efforts for provision of early childhood education were confined to the voluntary sector and received little or no support from the government (TorAnyiin, 2008). It was for the first time in 1977 with the introduction of National Policy on Education by the then military government of Nigeria that the importance and need for early childhood education was given official recognition and linked with the child's educational performance in primary school. Gradually, early childhood institution stayed, and by 1985, Nigeria had about 4200 early childhood educational institutions. While by 1992 the number increased to about 8,300 (Federal Government of Nigeria/UNICEF 1993).

Nowadays, early childhood educational institutions are located in various places and buildings compuses of universities and Colleges, premises of some industries and business organizations, church premises, residential buildings with unprecedented expansion owing to the high demand for early childhood care and education by parents (Ejieh, 2006).

\section{Concept of Early Childhood Care and Education}

Maduewesi (1999) refers to early childhood care and Education as the education offered to children who have not yet reached the statutory age of beginning primary school. He further maintained that it is a semi-formal education arrangement, usually outside home where by young children from about the age of 3 years are exposed through play like activities in a group setting through mental, social and physical learning suited to their developmental stages, until the mandatory age of government approved formal schooling. FRN (2004) refers to Early childhood care and Education (pre-primary education) as an education given in an educational institution to children aged 3-5 plus prior to their enrollment in the primary school.

\section{Objectives of Early Childhood Education}

The objectives of early childhood education according to FRN (2004) are:

1. Effect a smooth transition from home to school

2. Prepare the child for the primary level of education

3. Provide adequate care and supervision for the children while their parents are at work (on the farm, in the market or offices)

4. Inculcate social norms

5. Inculcate in the child the spirit of inquiry and creativity through the exploration of nature, the environment, art, music and playing with toys and so on.

6. Develop a sense of cooperation and team spirit

7. Learn good habits, especially good health habits and.

8. Teach the rudiments of numbers, letters, colours, shapes, forms and so on through play. 


\section{Basic Curriculum Provision of National Policy on Pre-Primary Education}

The FRN (2004) outlined some steps the government designed to achieve the objectives of preprimary education in Nigeria, which are as follows;

(i) Encourage private efforts in the provision of pre-primary education

(ii) Making provision in Teacher Training Institution for production of specialist teacher in Preprimary education.

(iii) Ensuring that the medium of instruction will be principally the mother-tongue or the language of the local community.

a. Develop the orthography for many more Nigerian languages, and.

b. Produce textbooks in Nigerian languages, FRN reported that some of these developments are already being pursued in the University Departments of linguistics under the auspices of some state ministries of Education. This Language centre will be expanded so as to have wide scope;

(iv) Ensure that the main method of teaching in the pre-primary institutions will be through play and that the curriculum of teacher training college is appropriately oriented to achieve this.

\section{Early Childhood Education and its Problems}

Nigerian education system since independence can best be described as a system riddled with crisis. It is not strange for this to be so, because we had inherited the system from our colonial master (Eriba, 2011). Judged against this premise, it becomes very challenging for Nigerians to manage the educational system passed to them by the British. So the system becomes inundated with diverse crises since independence. According to Eriba (2011), the educational system has been in a state of permanent crisis that it has lost quality, efficacy and functionality over the years. Early childhood education in Nigeria is not left out in these crises which tend to make the gains of education less spectacular. The challenges which these problems have precipitated for the nation will be highlighted in few key areas so as to provide a framework for considered action by the stakeholders.

\section{Proliferation of Early Childhood Institutions}

The official provision made in the National Policy on Education (FGN 2004) mandated the Government to encourage private efforts in the provision of early childhood education in the country. Moreso, owing to the high demand for early childhood education by parents, it does not take a long time for newly established early childhood institutions to grow and develop. According to Nwakaego (2007), it is becoming customary to operate a early childhood institution in every household. currently, early childhood education institutions are located in various places and buildings-campuses of some universities and colleges, premises of some industrial and business organizations, church premises, residential buildings some part or the whole of which are hired for use as early childhood schools (Ejieh, 2006). The flip side of this proliferation of early childhood institutions is that, the issue of standard and "regulations" have been waved off. The end result is that the young minds are offered "substandard" and "irregular" education that can not breed egalitarianism and self-reliant individuals of the society and leaders of tomorrow.

\section{Quality and Qualification of Teachers}

The quality of the teachers determines the strength of any educational system and the value of the learners (Okoro, 2004). In Nigerian early childhood institutions today, the teacher quality is generally low. It is only a few of the nursery schools especially those owned by educational 
institutions, private companies and wealthy individuals that can afford to engage the services of university graduate teachers and holders of Nigerian Certificate in Education (NCE) qualifications, competent and committed teachers and are also capable of retaining such teachers. Most others employ a few NCE teachers (if any at all), who are usually underpaid, while others employ mainly Grade Two teachers and secondary school leavers with school Certificate or General Certificate (ordinary level) qualification. In a situation where most of the teachers in our early childhood institutions are unqualified and/or unprofessional, effective teaching and learning cannot be achieved.

\section{In-effective Supervision of Early Childhood Institutions}

No educational plan however excellent it may be, can be effectively implemented if the school supervision is ineffective. State Ministry of Education officials are in principle, supposed to visit and inspect the physical plant, the human and other resources available in a proposed nursery school and if these are found to be adequate, the ministry would approve the school for operation. In most cases these visits are made a long time after the school had become operational and had been paying the prescribed taxes. The same is true in regard to teachers in nursery schools. Some of the people employed to teach the children are neither trained to teach nor do they know how to handle or relate to children.

\section{Language Policy Implementation}

Inspite of the laudable provision of the language policy nothing much seems to have been achieved. Firstly, the position of Nigerian language as a medium of instruction is hard to come by. The FGN/UNICEF (1993) reported that about $93.2 \%$ of teaching and learning in Nigeria preschools was done in English. The $6.8 \%$ use immediate language shows clear lackadaisical attitude towards the implementation of the issue of medium of instruction in mother-tongue or language of immediate community. This problem is likely to be connected with parents and pupils interest in English which has been in use since 1842, as well as its official position in Nigeria (Tor-Anyiin, 2008). The low literacy rate even in English indicates poor implementation of the language policy, he further maintained that lack of implementation of language policy has affected the quality of Nigeria Educational development.

\section{Teacher-Pupil Ratio}

The policy position of teacher pupil ratio of $1: 25$ is also not implemented due to lack of supervision or monitoring. In deed, since businessmen/women dominates this education sector, profit maximization is their main concern. As such, employing more teachers to maintain this ratio is not beneficial to them, hence, early childhood institutions have a ratio that depends on available children. This goes further to explain the accommodation problem of this educational level. Though higher institutions are now offering early childhood education courses, however, Government nonencouragement in terms of scholarship and teachers' poor financial remuneration is blocking many of the opportunities to go for such courses and help man the institutions. Indeed, since, the proprietors are money conscious their payment is not encouraging to warrant many people take to the study of early childhood education (Tor-Anyiin, 2008).

\section{Negligence on the Part of Government}

Of all the measures that Federal Government undertook in order to facilitate the achievement of the objectives of early childhood education, the only one it has effectively accomplished is the granting of permission for private efforts in the provision of early childhood education in the 
country, with virtually less or non participation by the public sector. This, in addition to lack of supervision to ensure the maintenance of standards, has led to increases in numbers of early childhood education institutions in the country. Significant provision is yet to be made in public or private teacher training institutions in the country for the production of specialist teachers, it is doubtful if it can attract many clients, as neither the Federal nor any state government has established any nursery or early childhood schools where graduates of such a programme can be employed. Work in private nursery or early childhood institutions would probably have no attraction for specialist in early childhood education teachers because of low wages and job insecurity associated with teaching in such institutions (Ejieh, 2006).

\section{Prospects}

The Universal Basic Education (UBE) Act (2004) has an expanded scope which includes programmes and initiatives for early childhood education and development. The UBE programme has made provision for every public primary school to have a pre-primary school linkage to cater for children aged 3-5 years. This linkage will serve as a strategy for getting children ready for school and school ready for children (Hua, 2010).

An inventory of ECC faculty in Nigeria conducted by FGN/NERDC/UNICEF in 2003 showed that most of the ECC facilities are private owned (42\% of the sample population are private owned and $34 \%$ by the government, followed by $21 \%$ by local communities). Now that the Early Childhood Development Programme is covered by the UBE law, government ownership at state/LGA/community level is certain to increase, particularly regarding centre's catering for the 35 years olds.

Early childhood care has been included in the Bachelor's degree curriculum of the Faculty of Education of some of Nigeria's Universities since 1991. The concept has also been integrated in the syllabus of Colleges of Education through out the country. In-services training on the early childhood development concept and learner centered pedagogy for handling young children is continually provided to teacher/caregivers in public ECC/ pre-school facilities in UNICEF supported 111 focus LGAs nationwide. However, only now it is being recognized that early childhood care and early stimulation is the basis upon which attainment of the child's fullest potential depends.

The Child Right Act (2003), the UBE Act (2004), the National Policy on Education, Food, Nutrition and Health are laws and policies which have given shape to different sectoral interventions on Early Childhood Care and development in Nigeria. Currently however, an Integrated Early Childhood Development (IECD) policy, that integrates interventions from the various sectors to promote an integrated holistic approach to the development of the child in its very earliest years.

Efforts are also targeted at vulnerable or disadvantaged children through community- driven and home based care and support for young children age 0-3 years supported by UNICEF in 222 focus communities nationwide has boosted access of very vulnerable and disadvantaged children to early childcare and early learning (UNESCO 2007). Launching of the children and AIDS campaign in Nigeria with increased focus, care and attention to children affected by the HIV and AIDS' scourge. Increased advocacy has been mounted with government and other stakeholders to ensure that young children are fully protected from the scourge of the disease.

According to UNESCO (2007), the curriculum for Early Childhood Education in Nigeria was reviewed and revised in 2003/2004 using an integrated bottom up approach, targeting children age 0-5 years. This revised curriculum has been approved for use by the government, and a training manual to facilitate use of the curriculum; is in process of development. the training manual is expected to promotes the integrated approach and cover all sectoral interventions- health, nutrition, water and environmental sanitation, psycho-social care, early learning and creating a conducive environment for them to service, live, learn and reach their full potentials. 


\section{Recommendations}

There is need for state ministry of education officials to enforce the regulations laid down by the Federal Ministry of Education in regard to the provisions of early Childhood Education. Effective quality monitoring units should be set up by ministries of education and provide with necessary logistic support to ensure that minimum standards are maintained in both public and private preprimary institutions.

Government should regulate salary of all teachers in early childhood education as well as school fees. The poor salary solely determined by respective exploiters of Early Childhood schools owners scare away many parents in sending their children. Poor salary denies such schools of professional or qualified and dedicated teachers hence children are denied quality education.

Respective state ministries of education under National supervision should handle the issue of orthographies. Decentralization will be more helpful as respective states will know the mother tongues or the language of immediate environment. More so, Local Government Education Authorities (LGEA) rather than states should assist in the production of textbooks in the spoken language in the area. Regular supervision and monitoring with stiff penalties for offenders will help to maintain the teacher-pupil ratio. This will also help teacher to supervise the learning experience of the play method.

Effective measures should be ensured in the training of early childhood/pre-primary teachers through adequate scholarships, approving the mounting of such programmes in all Universities, Institutes of Education and College of Education. Moreso, if Nigeria wants to achieve the objectives of education for all, then, there is need for Early Childhood Development to cover children of 03years.

\section{Conclusion}

The importance of a solid foundation in education is obvious. Early Childhood education is where the foundation is laid. Poor performance in the other levels of academic can be traced to this foundation level. So a thorough knowledge of what, and how education is been handled at this level is imperative. Therefore, government needs iron determination to implement the strategies that will necessarily enhance quality and quality development of early childhood/pre-primary education in Nigeria.

\section{References}

Bagudo, A.B (2008). The Relevance of early Childhood Care Development and Education in Achievement of Vision 2020 Farfuru J ournal of Multi-Disciplinary Studies, 3, 20-27.

Ejieh, M. U. C (2006). Pre-Primary Education in Nigeria: Policy Implementation and Problems Retrieved from http//:ikogretim-oinline.org.tr on the 11th February, 2011.

Eriba, J.O. (2011). Nigeria at Fifty: an appraisal of her Educational system. A paper presented at the 5th Annual National Conference of the School of Education College of Education Katsina-Ala on the 11th August 2011.

Federal Government of Nigeria and United Nations Children Cultural and Educational Fund (UNICEF) (2003). Situation and policy analysis of Basic Education in Nigeria. Paper present at the 2001 conference of African Curriculum Change.

Federal Government of Nigeria (2004). The compulsory Free Universal Basic Education and other Related Mattes Act. Lagos: Government Printer.

Federal Republic of Nigeria (2004). National Policy on Education (4th Ed). Lagos: NERDC Press.

Hua, R. (2010). Early Childhood and Development: Benue State situation. Paper Presented at the Workshop on Establishment and Strengthening Civil Society Organization (CSOs) Network for Effective Implantation of ECC/Gender Issues Programmes in Benue State at Gboko, Benue State. 
Maduewesi, E. J. (1999). Early childhood Education, Theory and Practice. Lagos: Macmillan Nigeria Publishers Limited.

Mahuta, M. G (2007). Introduction to Sociological Foundation of Education. Sokoto: But-Bass Educational Books.

Nwakaego, E (2007). Effective Implementation of the UBE Programme. Nimo: Rex Cherles \& Patrick Ltd.

Obidike, I.V (2012). Towards Effective Early Childhood Care and Education Programme in Nigeria. Journal of Teacher Perspective 6 (3) (507-513).

Okoro, D.C.U (2004). "Universal Basic Education," in E.A Yoloye and A. O. Osiyale (Eds) Burning Issues in Nigeria Education. Ibadan: Wamilore Press.

Tor-Anyiin, S. A (2008), Origin, Growth and Development of Pre-Primary and Primary Education in Nigeria. Makurdi: Selfer Academic Pres Ltd.

UNESCO (2007). Nigeria Early Childhood Care and Education (ECCE) Programmes; International Bureau of Education (IBE). Retrieved from efareport@unesco.or. On the 11th February 2011. 